$50 \mid 2019$

Animals in the religion and culture of the Tibetan

Plateau

\title{
Hunting for fortune. Wild animals, goddesses and the play of perspectives in early Tibetan dice divination
}

La chasse à la fortune. Les animaux sauvages, les déesses et le jeu des perspectives dans la divination par les dés au Tibet ancien

\section{Brandon Dotson}

\section{OpenEdition}

\section{Journals}

\section{Electronic version}

URL: https://journals.openedition.org/emscat/3747

DOI: $10.4000 /$ emscat.3747

ISSN: 2101-0013

\section{Publisher}

Centre d'Etudes Mongoles \& Sibériennes / École Pratique des Hautes Études

\section{Electronic reference}

Brandon Dotson, "Hunting for fortune. Wild animals, goddesses and the play of perspectives in early Tibetan dice divination", Études mongoles et sibériennes, centrasiatiques et tibétaines [Online], 50 | 2019, Online since 04 March 2019, connection on 13 July 2021. URL: http://journals.openedition.org/ emscat/3747 ; DOI: https://doi.org/10.4000/emscat.3747

This text was automatically generated on 13 July 2021

(c) Tous droits réservés 


\title{
Hunting for fortune. Wild animals, goddesses and the play of perspectives in early Tibetan dice divination
}

\author{
La chasse à la fortune. Les animaux sauvages, les déesses et le jeu des \\ perspectives dans la divination par les dés au Tibet ancien
}

Brandon Dotson

Scholars following "the animal turn" have often taken inspiration from Claude LéviStrauss's remark that animals are "good to think" (Lévi-Strauss 1963, p. 891). To riff on this, it may be the case that for the study of animals and religion, divination is also good to think. Augurs, e.g., "if you see a raven in the east at dawn [...]" or "if you hear a dog howl at midnight [...]" are one of the starkest examples one could imagine for the use of animals as a symbol system or a language. Animals also commonly appear in the oracular responses of divination texts, and this is certainly true of the majority of the oracular responses of the $9^{\text {th }}$ - and $10^{\text {th }}$-century Tibetan dice divination texts examined here. The agenda of animal studies pushes us further, however, beyond an anthropocentric approach to animals as objects in relation to human beings, or merely as expressions of human concerns, and challenges us to concern ourselves with animals as subjects in their own right $^{2}$. In these dice divination texts, as in early Tibetan funeral rituals, we find indications that animals - or at least some animals - could act as religious subjects ${ }^{3}$. An oracular response in a $10^{\text {th }}$-century Tibetan dice divination text, for example, reveals that one could perform this divination on behalf of a horse ${ }^{4}$. Most of the analysis in this article nevertheless concerns animals as contested symbols representing a struggle for fortune (phya) between human oracular gamblers and sman goddesses. As such, the animals in the oracular responses are symbolic of fortune, and they advertise the presence of their divine caretakers and of their human hunters. This struggle for fortune is itself the product, however, of an underlying relatedness that links gods, humans, wild animals, and domestic animals by the fortunate essence (phya 
and g.yang) that circulates between them. This essence - an index of relatedness - is what in turn defines each in relation to the other, and this underpins their orientations in the world, thus having real repercussions for animal lives.

\section{Early Tibetan dice divination}

2 It is notable that the theme of animals and divination is prominent at the very beginning of the subfield of Old Tibetan studies. The very first Tibetan Dunhuang manuscript from the Pelliot collection in Paris to be studied and translated by a European scholar was in fact a text on raven divination. Jacques Bacot published his translation of the text, Pelliot tibétain (abbreviated hereafter "PT") 1045, in the year 1913, and Berthold Laufer published his longer study, based on Bacot's transliteration, the following year.

3 As divination typologies go, raven divination belongs to the category of auguromancy, or the interpretation of signs and augurs according to their situation in time and space. This is to be distinguished from cleromancy, or the manipulation of randomizing objects, under whose rubric dice divination falls. Animals feature heavily in auguromancy, not only in raven divination texts, but also in astrological and hemerological (that is, calendar-based divination) texts, where in addition to the cries of ravens or crows, the barking of dogs and the chewing of rats through one's clothing can be significant portents depending on when these occur ${ }^{5}$. These are just one of many important indicators concerning Tibetans' attitudes toward particular animals, though here one must also keep in mind that many of these traditions, along with their sensibilities, were imported to Tibet from elsewhere ${ }^{6}$.

4 Turning to the Old Tibetan dice divination texts that concern us here, scholars such as F. W. Thomas, Rolf Stein, and Michel Strickmann have all noted in one manner or another the prominence of animals in these texts (Thomas 1957, p 116, Stein 1971-1972, p. 447 , Strickmann 2005 , pp. 129, 133). Thomas was struck by the oracular verses and the gods, animals, and places they evoked, which he felt lent these divinations a particularly Tibetan character (Thomas 1957, p. 116). Stein emphasized the role of sman goddesses in the responses, describing these goddesses as possessors of wild animals, especially cervids (Stein 1970-1971, pp.446-447). Stein also stated that the sman themselves sometimes appear as deer or as aquatic birds, and he even proposed a possible connection with the international folklore motif of the Schwanenjungfrau or swan-girl (Stein 1970-1971, p. 447). Michel Strickmann, in his wide-ranging study of divination across cultures, emphasized the presence of animals in divination, specifically in Central Asia: "[a]part from birds and their analogues, the study of oracular animal-imagery in general could prove fruitful. It might well begin with those Central Asian systems in which animals seem to have played a primary role, but many other oracles abound in portentous fauna, from ancient Greece to modern China" (Strickmann 2005, p. xxv). It is in part the preponderance of animals in early Tibetan divination texts that prompted Strickmann to propose a close connection between early Tibetan dice divination and other Central Asian (e.g., Turkish) divination traditions (Strickmann 2005, p. 133).

5 In order to better appreciate the place of animals in early Tibetan dice divination, it will be necessary to first introduce this system's methods. Early Tibetan dice divination is known to us from around twenty manuscripts identified in the finds from Dunhuang, 
Turfan, and Mazār Tāgh (Nishida 2008, Nishida forthcoming). All but one of these manuscripts is in scroll format, and these date mostly to the $9^{\text {th }}$ century CE (Takeuchi 2012, p.9). The method of dice divination that they describe was almost certainly transmitted to Tibet from the Indic world, and there is also a Runic Turkish and a Chinese text at Dunhuang that employ the same method ${ }^{7}$.

6 Early Tibetan dice divination employs three rectangular four-sided dice, known as pāśaka-s in Sanskrit. These are generally made from bone, ivory, stone, or terracotta, and are typically found in longer $(7-9 \mathrm{~cm} \times 1 \mathrm{~cm} \times 1 \mathrm{~cm})$ and shorter $(3,5-5 \mathrm{~cm} \times 1,5 \mathrm{~cm}$ $\mathrm{x} 1,5 \mathrm{~cm}$ ) varieties.

Figure 1. Four-sided die, red terracotta from Khyber Pakthunkhwa in northwest Pakistan; Gordon bequest, British Museum no. 1880,1483

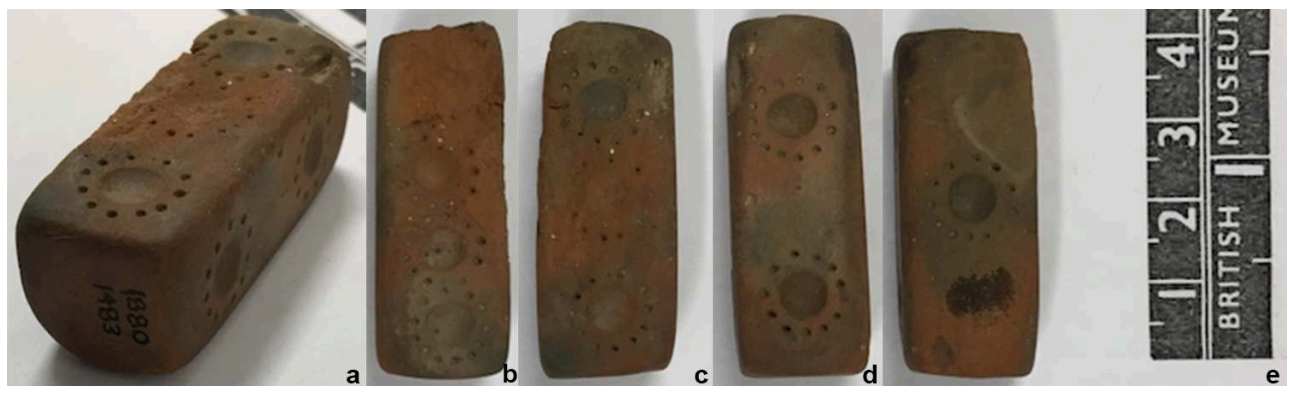

Figures $b$ though e show each of the four sides. Note that one of the pips has broken away on the side that should have four pips.

(c) Photographs by Brandon Dotson. Courtesy of the British Museum

7 When three dice are cast, their pips are combined to arrive at one of 64 possible combinations, e.g., $4 / 1 / 4 ; 1 / 4 / 4 ; 4 / 4 / 1 ; 3 / 1 / 2$, etc. Each such combination indexes one of 64 written responses in an accompanying divination text, at the head of each of which appears an arrangement of circles representing a given combination of dice pips. 


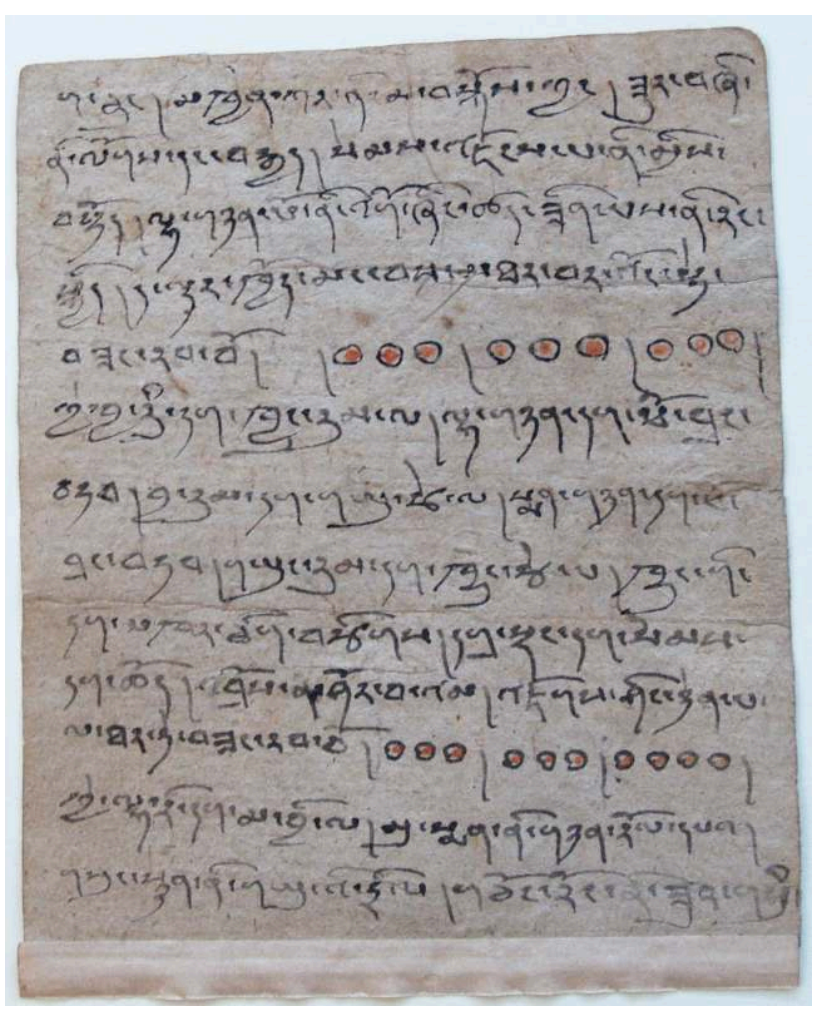

Here the representations of the pips use red ink, and do not set the text off into "paragraphs" or sections, but rather appear in the same line as the preceding and following text.

(c) Photograph by Brandon Dotson. Courtesy of the British Library

The ritual procedure for performing this early Tibetan form of dice divination is described in a verse introduction to a $10^{\text {th }}$-century dice divination codex, IOL Tib J $739^{8}$. It is the only such extant introductory invocation, since most of the other Old Tibetan divination texts are missing their beginnings and/or ends, or simply lack an opening invocation. In poetic language, the introduction invokes the sun and moon, summer and winter, the four directions, and six types of animals. It then calls on seven groups of goddesses, each referred to by the Tibetan term sman. These groups are arrayed along a descending vertical axis that proceeds from the sky down to the snow mountains, slate, high meadows, crags, and lakes. At the head of the seven groups of goddesses is the great goddess gNam sman dkar mo, who figures prominently in both the Gesar epic and in the Bön pantheon. The goddesses are offered jewels and they are given food offerings and libations.

Evoking the ritual setting, the verses mention ritual gifts (yon) and fees (yas) to be offered to the diviner (mo bdag), who reads out (klags) the relevant written divinations $(m o)$. It closes by explaining the method for casting the dice, though the verb used for this action is not the causative "rolling", "casting", or "throwing", but the resultative, non-volitional "falling", or "descending" (babs) (Thomas 1957, p. 115). Namely, it states that three sets of "dice falls" should result in three oracular responses. If one receives either three good or three bad responses, then this is definitive. Should one receive two bad and one good, it is permissible to cast the dice once more for a further divination. In the inverse case, however, the result is set aside entirely, and the result of the divination consultation is neither good nor bad, but null (Dotson 2015, p. 152). This is 
an example of "resistance", whereby a divination system asserts its independence and thereby its objectivity by refusing to serve its users.

Each of the 64 entries corresponding to a given "dice fall" typically includes four component parts (Thomas 1957, p. 115, Dotson 2015a, pp. 153-154"). The first is the pips or symbols (e.g., numbers or letters) that index each response. This might be referred to as an "omen", in the sense of a naturally (or randomly) generated sign. The second element is an imagistic utterance, sometimes from the mouth of a deity, and sometimes rendered in $v^{2} \mathrm{se}^{10}$. Rolf Stein, underlining their allusive nature and their detachability, referred to these utterances as "poems" (Stein 1970-1971, p. 440). One might equally refer to this element as an "oracle" in the sense of the mantic interpretation of the preceding sign, as in the classic divinatory semiotic paradigm of

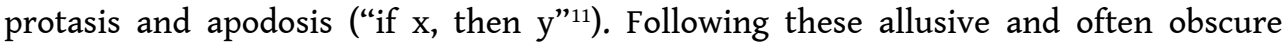
words, the third component is a prose explanation of the applicability of the poem or oracle: it may be good for trade, family, health, defeating one's enemy, and so forth. I refer to this as a prognosis or an interpretation. Lastly, the fourth component is a summation or evaluation that simply states, "this is a good divination", "this is a bad divination", or "this is a middling (that is, mixed) divination". There is some variation across the texts, and some entries include further components such as instructions to worship gods or to perform correcting rituals ${ }^{12}$. There are texts in which entries lack one or another of these four components, but this schema remains useful as a standard by which to describe diverse oracular responses.

11 The entries in a divination text refer to themselves as "divinations" (mo), particularly in their summations, e.g., "a good divination" (mo bzang ngo). Mo also refers to the ritual procedure and to the greater tradition of divination writ large. In the future-oriented prognoses - the third element above - we also find the term ngo (or the honorific equivalent, zhal), which I translate with "augur" or "prognosis". Sometimes one also encounters the term "sign" (rtags). As will be evident below, I often use the terms "(oracular) response" or "entry" to refer to a passage or to an entire entry in a divination text. Most of these pertain to the second and third elements, the "poem" or "oracle" and the "interpretation" or "prognosis".

\title{
The comingled fortunes of humans and livestock
}

\author{
[Dice Rolls:] 000/000/0 \\ "Oh! Up on the northern plains \\ Over there - they seek seven gazelles. \\ The thieves shall never get them \\ They are the property of the mu sman goddesses". \\ This has fallen on the divination of the sman goddess rGod spangs she le. If you have \\ cast it for household fortune and life-force fortune, then the fortune of humans will \\ be undiminished and the fortune of livestock will be undiminished. The gods \\ protect your happiness and long life. If you undertake some matter, it will be \\ accomplished. If you've cast this for a sick person, s/he will recover. If you've \\ requested an official post, it will be given. If you've cast it for subsistence fortune, \\ you will have subsistence. If you've cast it for companionship/marriage, you will \\ meet it. If you go for trade, you will make a profit. If you've cast it for a visitor, s/he \\ comes near. For whatsoever you've cast it, this divination is extremely good. \\ @@@ / @@@ / @ / kye byang ka nI ya bya ${ }^{13}$ na dgo bdun nI phas kyang 'tshal / / rkun pos \\ nI re myI 'tshal / mu sman nI nyid gI dkor / / mo 'dI sman rgod spangs she le'i mo la bab ste \\ / / khyIm phya dang srog phya la btab na / myI'I phyva myI nyams / / phyugs kyI g.yang
}


myI nyams / / dga' skyId tshe rIng lha srung / don gnyer na grub / nad pa la btab na sos / rje blas gsol na gnang / / srId phya la btab na srId yod / gnyen byas na 'phrod / / tshong byas na khye phyIn / / 'dron po la btab na nye bar 'ong / / mo 'dI cI la btab kyang bzang $\mathrm{rab} / / /$. (IOL Tib J 738, 3v91-95; Dotson 2015a, p. 155) prognosis section of an oracular response, which helps to suggest to what uses dice divination was put. It also includes some important information regarding the semantic fields of "fortune" in Tibetan. Specifically, the prognosis uses different terms for the fortune of humans (myI'I phyva) and for the fortune of livestock (phyugs kyI g.yang) (Dotson 2015a, p. 158, n. 17). This distinction between phya - sometimes spelled phyva in our sources - and g.yang can be found in many other contexts ${ }^{14}$. We also find the distinction between human fortune and livestock fortune in other oracular responses such as this one:

[Dice rolls:] 0/0000/0000:

Oh! The divine lord in his fortress

Human, receive the phyva!

Livestock animal, receive the g.yang!

The upright [= human] becomes ever more glorious.

The bent-over [= animal] becomes ever more gentle".

@ / @@@@ / @@@@ / kye lha rje nI khyung mkharna / / myI cIg nI phyva long cig / / phyugs [cIg?] nI g.yang skyobs cIg / / 'greng la na ${ }^{15}$ brdzId re che // dog la nI 'o re byams.

(IOL Tib J 738, 1v53-54'16)

theme that accords with what one finds in some later materials, as we will see.

application of phya to humans and g.yang to livestock also brings up a point about the semantic fields of animals in Tibet. In particular, phyugs refers to livestock in the form of bovids (cattle, $m d z o$, yaks, etc.) and also sheep and goats. This term does not usually include dogs or horses. Birds, as "winged things" ('dab chags), belong to their own category, as do predatory animals, which are "carnivores" (gcan gzan). Wild cervids, equids, caprids, and bovids - game animals - are referred to as ri dags, indicating their belonging to the hills and to the wild. One of the few binary oppositions between human and animal is found in the compound 'greng dud, "the upright ones and the bent-over ones", used customarily in the context of describing those over whom the Tibetan emperor has dominion (Uray 1966). Even here, however, although Uray chose to translate dud with "animals", he noted its connection to "maned [animals]" (rngog chags), especially horses. So it is clear that dud has a much narrower semantic range than the English term "animal", and should not be taken as a general Tibetan term for "non-human animal". The same is true of the term dud 'gro. To this one could add many further observations about semantic fields relating to distinctions between types of animals, their ages, and sexes, but the most important for our purposes are phyugs "livestock" and ri dags "wild [game] animals".

Alongside these fairly clear distinctions between human fortune and livestock fortune, there are also in fact many instances where the two categories overlap. In two divination texts we find the same line: "when phyva escapes, so does g.yang, and one gets weaker with each breath" (phyva bros nI g.yang mnyam te / nyams chung nI dbugs re phra /; PT 1051, l. 20 $)^{17}$. In another oracular response, it appears that g.yang has the power to extend human life.

[Dice rolls:] 0/0000/0000:

lHa rje ltang dkar [says]: 


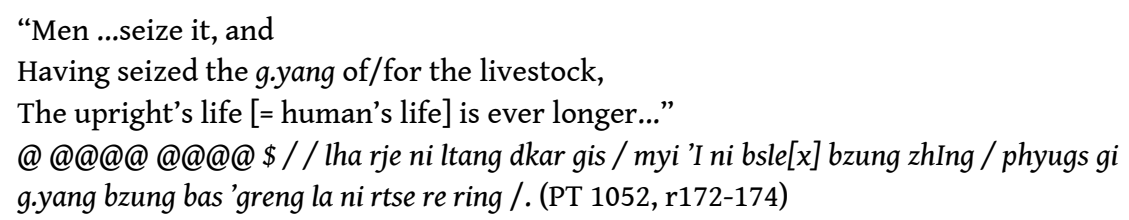

The relevance of g.yang to human fortune (myi phyva) is clearly stated in a further oracular response.

[Dice rolls:] 0/000/000: From the mouth of [the god] Sla bo sla sras: "If human fortune (myI phyva) has escaped, summon the g.yang! If a horse has gone missing, search for the horse! If one's turquoise breaks, use an awl to fix it! If one repays a debt of fortune with fortune (phyva), it is good 18 ".

@@@@@@@ :/ / sla bo sla sras gyI zhal nas myI phyva bros na g.yang lon cIg rta rlag rtas 'tshol cIg / g.yu chag na gsor gyIs sob cIg pya bun gyI phyva blan na bzango /. (IOL Tib J 740, 11. 225-227)

This reinforces the image, already seen above, of human fortune as something that can escape or flee (bros). The way to rectify this situation of lost phyva, likened to searching for a lost horse or fixing one's turquoise, is to perform a ritual to summon g.yang, whose breadth of meaning in this way overthrows a narrow translation like "animal fortune".

This overlap between phyva and g.yang is probably not due simply to fuzzy distinctions between different Tibetan categories of fortune and luck, to which one could add rlung rta, lam 'gro, and skal ba, as well as bsod nams, dbang thang, dbu 'phang and other terms related to one's status (Lichter \& Epstein 1983, Calkowski 1993, Karmay 1998, Kelényi 2003, da Col 2012a). Rather, it is also the result of the close relationship between humans and their livestock, who form the basis of their wealth and livelihood: an increase in the fortune of one's livestock is also a very real increase of one's own fortune. The point is made succinctly by the polysemy of the Tibetan word nor, which means wealth, but also livestock. There are also the close homophones phyugs ("livestock") and phyug ("wealth") and the compound phyug nor-sometimes spelled phyugs nor - to indicate a man's possessions in Old Tibetan legal codes such as the law of accidental homicide and the law of theft (Richardson 1990, p. 162, n. 11 ${ }^{19}$ ).

The manner in which the jurisdictions of phya and g.yang are both distinguished and blurred in early Tibetan dice divination texts is in fact very similar with what we find in later Tibetan ritual texts dating from approximately the $12^{\text {th }}$ to the $20^{\text {th }}$ century. Some of these include myths of the origin of phya and g.yang, and have been recently studied by John Vincent Bellezza (2005), Daniel Berounský (2014), and Charles Ramble (2015). For Bellezza:

g.Yang is the potentiality, capability or power for good fortune found in people, animals, deities, and other auspicious objects expressed in terms of good luck, wealth, happiness, and all other positive qualities and conditions. It is commonly thought to exist with a phenomenon known as phya/phywa - the undifferentiated capability for good fortune and auspiciousness, which serves as the basis for human sustenance and endeavour. (Bellezza 2005, p. 456)

Berounský translates phya with "good fortune" or "good destiny", and states that it has a close relationship with tshe "lifespan" or "longevity", for which it can sometimes be a synonym. He translates g.yang with "prosperity" or "well being" (Berounský 2014, p. 55). Ramble, building on Karmay's definition of g.yang as "quintessence of fortune" (Karmay \& Nagano 2002, p. x), notes that in the texts he has translated, "a horse without g.yang is no different from a wild ass [kiang], and a yak without g.yang is like a 
'brong, a wild yak. It is g.yang that gives these animals their 'horseness' and their "yakness"' (Ramble 2015, p. 510). Ramble also notes that "it is clear that phya is more closely associated with humans, and g.yang with animals: phya is to humans what g.yang is to livestock, lustre is to turquoise, warmth to clothing and nutrition to food". He specifies further, however, that the two categories overlap such that humans can have g.yang and animals can have phya (Ramble 2015, pp. 510-511).

Giovanni da Col treats g.yang (phonetics: yang) as a central component of what he describes as the "field of fortune" comprising and surrounding the individual or person (or "container") among Dechen Tibetans in Yunnan:

Among these externalities composing one's field of fortune, the most important yang - is not a power in itself but a potential enhancing the efficacy of material and non-material things and beings, including faculties and skills: the yang invocations summon the yang of religion, law, trade, wealth, fighting prowess, and crops. Yang is a principle of vitality and germination: if there is no yang, crops will not grow, livestock will not thrive, and humans will become sick. Yang does not "directly" influence the events of the world in the sense 'our' luck does but only those related to the vitality, prosperity, and reproduction of a household or any other 'contained' social aggregation of humans or non-humans, such as wealth, livestock, fertility, and status. (da Col 2012b, p. 180)

Da Col goes on to describe how gods participate in this economy of fortune, gaining or losing g.yang in relation to human communities. "Non-human entities such as Tibetan sacred mountains and territorial gods (yullha zhidak [yul lha gzhi bdag]) possess a domain of yang [g.yang], which can be enriched by human offerings, or weakened by defiling actions (dip [grib]) or crimes against their possessions, such as hunting" (da Col 2012b, p. 180). Although this pertains to a specific ethnographic situation that features Naxi and Chinese influences, it is striking how closely this economy of fortune resembles that which is expressed in early Tibetan divination texts ${ }^{20}$. Here, as we shall see, the mention of hunting is also instructive, even if this reference is inflected by Buddhism to a far greater extent than are our early Tibetan dice divination texts.

Da Col, who has theorized g.yang in more detail than any other scholar, and who does not shy away from comparing it to $m a n a^{21}$, also describes g.yang with respect to its semantics:

Fortune cannot be "produced" (drub [grub]) out of nothing but has to be obtained from the outside, at least in an initial germinal form, and reinvigorated periodically. Yang [g.yang] is neither quantifiable, nor visible, but has a quasi-relational materiality. Yang can be summoned (gu ['gugs]), appropriated (len), called (bo ['bod]), "welcomed" as a guest would be (su [bsu]), or "raised" (so ['tsho]), like children or livestock, and made literally to "stick" or "attach" (chak [chags]) to places or objects fit to support it (yang ten [g.yang rten]). Without being attached, preserved, or contained properly within a "fortune-prone" support for its growth, yang does not have any efficacy: it remains inert, like a resilient virus, and slowly returns to the "outside". (da Col 2012b, p. 180; brackets added)

The relationship of gyang to the mountain and to the "outside", as well as its unproduced and quasi-substantial materiality are also pertinent to the way in which early Tibetan dice divination imagines phya and its circulation. As we will see, phya can also be "won" by humans through dice divination.

These descriptions of phya and g.yang come largely from studies of widespread rituals for summoning these fortunate essences, which can still be observed in Tibetan communities today. Typically, g.yang is "called in" (len) or "summoned" ('gugs), either 
to a village as a whole in a communal ritual, or to a household in a private ritual. The key ritual implements for summoning g.yang or phya are an arrow, held in one hand, and the foreleg of a deer or a sheep held in the other, with which the g.yang summoner directs fortune towards his client while shouting "khu!" or "khu ye!" (Ramble 2015, p. 513). The sheep, Ramble argues, serves as a suitable substitute for the ideal animal, the deer (Ramble 2015, pp. 513-514). Here it may also be relevant that the term g.yang also means "sheep" in many early Tibetan texts, and that this may also be a loan word from the Chinese yang 羊 (Berounský 2014, pp. 55-56). As to where this g.yang originally comes from, a variety of myths claim that it originated from a primordial deer caught by a mythical divine hunter (Ramble 2015). We will return to the significance of these hunting motifs and their relevance to early Tibetan dice divination.

Many of the charter myths for g.yang-summoning rituals, which constitute a discourse on the nature of both phya and g.yang, also specify that wild animals and wild spaces are the sources of fortune. One $18^{\text {th }}$-century ritual text for calling in g.yang states that phya "signifies descent from the sky to the earth", and g.yang "signifies the acquisition of nutrition" (Ramble 2015, p. 524). The latter could obviously be said of hunting, and the vertical axis from heaven to earth is also one that proceeds from the wild mountains and highlands to the cultivated lowland valleys. In this and other texts and performances of such rituals for calling in fortune, it is clear that fortune resides in wild animals and in wild spaces, and that the aim of the ritual is to transfer this fortune to humans and to their livestock.

The motif of descent from heaven to earth is clearly present in early Tibetan divination texts as well. A clear vertical axis is invoked in the opening to the divination text IOL Tib J 739, which proceeds from groups of sman goddesses of the sky to those of mountain, slate, meadow, crag, and lake. The most common places evoked in the divination texts are highlands ringed by snow mountains, and one very often finds the phrase "up there" (ya byi la). This points to the manner in which Tibetans conceptualize space, particularly vis-à-vis domestic space and wilderness. The relevant Tibetan terms are $y u l$ and ri. Yul is domestic space characterized by cultivation and by lowland valleys. $R i$ is wild space, imagined as being high, "up there". The term also means "mountain", and emphasizes how the continuum of wild and tame is conceived of along a vertical axis. The term for wild animals, particularly those that are hunted, is ri dags, which means, "belonging to the wild" or "belonging to the mountain". It is down from the high, wild repositories of fortune that one brings the phya and the g.yang into the domesticated spaces of lowland valleys and villages, to be incorporated into the fortunate bodies of the humans and the livestock dwelling there.

\section{The oracular gambler between wild animals, goddesses, and hunters}

Early Tibetan dice divination is similar to g.yang-summoning rituals in that it shares the goal of increasing one's fortune. Dice divination provides a radically different mode of interaction with fortune, however, where the balance is tipped further towards uncertainty, and where there is a greater element of risk. It is in one sense a distinction between the ritual work of a scripted fortune-summoning ritual on the one hand, and the more hazardous, uncertain, and playful technique involving the use of dice on the other. The randomizing technologies of cleromancy are often taken very seriously and 
executed with solemnity, but dice, as a technology of gaming, do tend to bring with them a sense of play. The recurring images of contest and of the hunt strongly suggest that dice divination was not simply a prognostic technique or even a ritual for revealing one's status vis-à-vis fortune, but rather a ritual for improving, or "winning" fortune. The risk inherent in this type of exchange, in which one enters into a relationship of "adversarial partnership" with the goddesses who oversee fortune and the wild animals and spaces in which it inheres, is also clear from the correcting rituals that are prescribed if one receives a particularly bad oracular response. In recognition of these dynamics, one could justly refer to this form of early Tibetan dice divination as "oracular gambling", the aim of which is to increase one's fortunate essence or phya, and thereby improve one's prospects with respect to health, wealth, family, etc ${ }^{22}$.

Wild animals and the sman goddesses who are their guardians or "owners" are central to the exchange of fortune at the heart of early Tibetan dice divination. That the sman are conceived of as the owners or possessors of these wild animals is clear from several oracular responses. One reads, "The divine mountain is a great refuge, so the deer and the kiang do not wander to the edges. By the love of the mu sman goddesses, those belonging to the sman goddesses thrive and increase" (zhing lha ri nI skyabs che bas / sha rkyang ni mtha' myi g.yo / mu sman gI 'o byam bas / sman dags nI 'pel rags; PT 1052, r212-214). In this response and in others we find wild animals such as deer, gazelles, and kiang referred to not only with the usual term, ri dags (literally, "belonging to the wild/ the mountain"), but with the term sman dags, that is, "belonging to the sman goddesses".

Such is also the case in the following response:

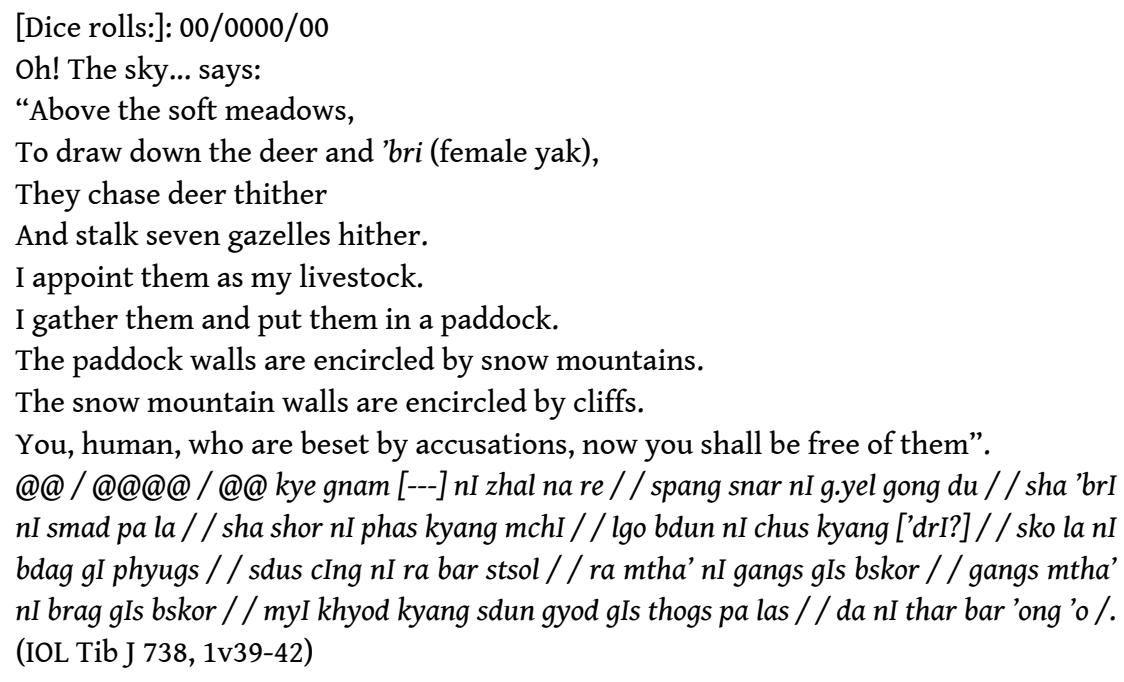

We can assume from the existence of a closely overlapping response in IOL Tib J 739 that the divinity speaking is a sman goddess. In this latter response, she makes the animals her "property" (nor), which stands in the corresponding place of phyugs in the above passage ${ }^{23}$. Here the image of the goddess corralling the wild animals and housing them in an enclosure or paddock is a wild corollary of the human domestication of animals ${ }^{24}$. The relationship between the goddess and the deer, yak, and gazelle is clear: she is their owner, and they are to her as livestock are to humans. Toni Huber and Giovanni da Col have noted similar dynamics in more recent Tibetan contexts where mountain gods view game animals as their livestock and wish to protect them from hunters ${ }^{25}$. The sman goddess' ownership of the ri dags animals, which are "livestock" 
(phyugs) from her perspective, focuses attention on the nature of the exchange with human hunters and oracular gamblers, and more specifically on the question of theft.

That the sman goddesses possess or own wild animals in an analogy with humans and their livestock is also clear from the oracular response with the seven gazelles given at the beginning of the previous section. It states that the gazelles are the sman goddesses' "property" or "possessions" (dkor), a term that also overlaps with the semantic ranges of nor and phyugs. This also includes an element of contest, and even of violation: the sman is trying to protect her possessions from thieves who would steal them.

In other oracular responses, those who would take such animals are often hunters (rngon pa):

[Dice rolls:] 00/000/00:

Oh! Up there, upon the meadows,

A stag is given chase!

Seven hunting dogs surround it,

It cannot escape, and is like something constricted.

The sman animal, she herself,

Is surrounded by seven hunters.

They encircle her, wherever she goes.

@@ / @@@ / @@ / kye spang ka nI ya byI na / sha phonI khyus chags pa / / rI khyI nI bdun gIs bskor / / myI shor nI dam dam ltar / / sman dag nI dngos cIg ma / / rngon pa nI bdun gIs bskor / / bskor cIng nI cI ru mchI /. (IOL Tib J 738, 3v37-38)

The consequences of this oracular response are grave. It portends gdon demons in one's household, death for a sick person, and it signals that one's fortune (phya) will escape ${ }^{26}$.

Apart from human antagonists such as hunters, sman goddesses and their wild animals also fear the predations of gzed or gzed po, a class of divine beings that come for the sman's deer or other animals. Had these gzed po not appeared in another Dunhuang manuscript alongside various classes of deities (PT 1060, 1. 52), and had they not been attested, albeit thinly, by later tradition (Nebesky-Wojkowitz 1956, p. 309, Norbu 1997, p. 82, Stein 2010, p. 269), one could be forgiven for assuming that they too appeared as hunters within the oracular responses. One response, which occurs in two separate divination texts, includes these gzed po in an image that contains important information about the types of exchange that are in play. It also gives a further sense of the risk involved in oracular gambling.

The mu sman says:

"The lha ${ }^{27}$ mountain and the byang mountain, the two,

Both are the mountains of the gzed.

From the depression of the sman mountain,

The thin-necked [bird?] reaches the peak.

It proceeds to the stong sgo of the gzed po

And to the waters of the mu sman.

When it gave a deer or a female yak

In order to offer to the gzed po

It gave one from among the sman-s' animals.

Still, [we] have not received recompense.

Up above, offer to the gods;

Down below, press down the sri demons".

This has fallen on the divination that displeases Je'u gnam sman. Previously I, a great sman, was protecting you, human, but now I make great and evil hindrances for you. The sman and the gods are displeased. Even if you were to go to the land of the 'dre demons or the gdon demons, or to enter a land to which you've never before been, still you will bring [this bad fortune with you] and there's no getting rid of it. 
Having arranged mo and phya [divinations], and performed rituals (bon), and searched for the hindrances, it would be good if you offered to the sman and to the sacred gods. If you don't do thus, it is a bad divination. This divination is bad for other things, [but] if you have cast it to go hunting wild animals or to take care of a particular matter, or for relatives' fortune/ marriage fortune (gnyen phya), then it will be accomplished, and it is an excellent [divination].

\$ / /:/:/ / mu sman nI zhal na re / / lha rI ni byang ri gnyis / / gnyI ga nI gzed gi ri / / sman ri nI gtsug sdings / / las / / mgrin phran nI rtse 'jos shing / / gzed po nI stong sgo ru / / mu sman nI chab la gshegs / / gzod ${ }^{28}$ po nI gsol pa la / / sha 'bri nI gcig gnang na / / sman dag nI gang las gnang / / da dung nI lan ma thob / / ya rus nI lha mchod la / / mar du ni sri gnon cig / / 'di nI je'u gnam sman myI dgyis ${ }^{29}$ pa'I mo la bab ste / / snga na sman chen po zhig gis srung srung ba las / myi khyod la bdag gis ngan pa'I bgegs ched po zhig byas te // sman dang lha myI dgyes ste // 'dri ${ }^{30}$ yul gdon nam yul gang yang ma shegs pa cig du zhugs te / / da dung khyer te thob pa nI ma yin / / mo phya dag gdam cing bon byas ni bgegs brtsal te / sman dang lha dpal mchod na bzang ngo / / de ltar ma byas na mo ngan no / / mo 'dI gzhan la ngan / / ri dags shor nab ${ }^{31}$ dang dor ${ }^{32}$ gnyer ba dang / gnyen bya ba la btab na grub ste bzang rab bo//. (PT 1051, 1l. 3-1033)

There are a few difficulties with this passage, in particular the assumption that "thinnecked" (mgrin phran) refers to some sort of bird, on which I have followed Ariane Macdonald. What remains clear, however, and what is central to the relationship between the oracular gambler and the sman goddess, is the principle of recompense (lan btab pa), whose rupture has offended the goddess: her animals were taken, and she was not repaid. It is intriguing that while the prognosis is negative, and presents one with an inescapable obstacle placed there by the sman goddess(es), it will be transformed to indicate a positive outcome once one diagnoses the situation through divination (mo and phya) and rituals (bon). (This mention of a diagnostic divination may be selfreferential and redundant, since this oracle itself and its interpretation have already traced the problem to the displeasure of the gods and the sman). Then, as in many other oracular responses, one changes the outcome through correcting rituals, typically in the form of offerings to the sman and the gods. It is also notable that while this response is bad for most things, it is good for hunting (ri dags shor).

The mention of hunting as one of the activities that concerns divination clients, as well as the repeated appearances of hunters in the responses, where they attempt to steal game animals from the sman goddesses, raises the question of the precise nature of the relationship between hunting and dice divination. Do these images of contest between human hunters and the natural and supernatural world of game animals and goddesses have any connection to actual hunting? We can answer this in the affirmative with recourse to a few further oracular responses which, like that just given, state one's prospects for hunting alongside the customary interpretations concerning wealth, health, travel, enemies, and so forth.

[Dice roll:]: 0000/0000/0:

Lha myi lha rgyung says: "When the rain falls from above it will not fall on the chicks' nest. When the great river bursts its banks, it will not flood the fields". If an enemy comes, you will defeat the enemy. If you've cast this for hunting, you will have success/ will kill. A good divination.

@@@@@@@@@ :/ / lha myI la rgyung gyI zhal nas char yas bab na bye'u tshang du char myI bab / chu chen / po brug na zhIng myI khyar / dgra byung na dkra thub rI dags la btab na sode mo bzango /. (IOL Tib J 740, 11. 10-12)

In the same text, a roll of $0 / 0 / 0000$ also returns an auspicious response with a similar result of defeating one's enemies and succeeding at hunting (IOL Tib J 740, 11. 190-193). Prospects for hunting are also mentioned in an oracular response at IOL Tib J 740, 
11. 126-127 and at IOL Tib J 738, 3v8-13. All of this clearly demonstrates that hunting alongside trade, health, marriage, family, friendship, lawsuits, and enemies - was one of the human concerns of these dice divination clients or oracular gamblers.

More fundamental to the ritual process of oracular gambling that these texts imagine, we might ask with whom the oracular gambler is invited to identify. Is it with the hunters or with the wild animals and their divine guardians? Put more simply, where a response includes hunting, is a successful hunt a good augur, or is it a good augur if the animal escapes?

In the case of the oracular response with the seven gazelles, it is clear that an analogy is drawn between the oracular gambler and the gazelles. Just as the gazelles get free from the hunter, so too will the client be free from accusations. Similarly, the stag encircled by seven hunting dogs, and the gazelle surrounded by seven hunters are bad augurs. The clear implication is that the oracular gambler is invited to identify with the hunted animals and to be thankful for the protection of the sman goddesses. The analogy between game animals and the oracular gambler or divination client is also clear in the following oracular response, whose result is auspicious.

[Dice rolls:] 0000/00/0:

Lha myi la rgyung says:

"The wild animals are there, residing in the highlands. Though they are innocent, everyone tries to kill them. Not killed upon that site, they escape through the eternal juniper brush nearby, and they shall be eternally deathless. You, man, will also live a complete number of years, like an eternity".

@@@@@@@ :/ / lha myI la rgyung gI zhal nas rI dags sa mthon po na 'dug 'dug pa dang / ma nyes par gun gyIs bsadu brkalte ma sod nas gnas gyI steng g.yung 'drung gi shug pa drung du bros nas g.yung 'drung gI myi 'chI / myI khyod gyang lo grangs tshang bar g.yung 'drung dang 'dra'o /. (IOL Tib J 740, 1l. 34-38)

41 What would seem to be on the face of it an anti-hunting sensibility is reinforced by many more images in the responses that feature hunters or gzed po making (or being prevented from making) the characteristic shout of the hunt, khus! We see this phrase, "to shout" or "to make shouts" (khus btab) in a yak hunt in the Old Tibetan Chronicle, in the case of catching a wild horse in an early Tibetan funerary text, and in several other passages in early Tibetan texts (Dotson 2013, pp.63-65). In the following oracular response, we find these hunting shouts in a further scene in which escaping animals are a good augur for the divination client.

[Dice rolls:]: 0/00/000:

Oh! In the three upper valleys, up above,

The pale grassland, on the golden ridge,

Seven men, hunting deer;

At one deer, they make a shout, khus!

In the three lower valleys, down below,

Three otters, they are weary.

Exhausted, and oppressed by hunger,

They fear an enemy, but there is no danger.

A good divination.

@ /@@ /@@@ / kye phu sum ni ya byi la / spang snar / ni gser sdongs la / sha shor ni my[i] bdun kyis / sha gcig ni khus btab pa' / mda' gsum ni ma byi na / gyur gsuM ni thugs snyung ba' /'o brgyal ni 'gres kyi non / dgra zhig la dogs pa las nyen myed de bzang rab bo. (IOL Tib J 739, 17r10-17v6; Dotson 2013, pp. 63-64. Cf. IOL Tib J 738, 2v19-24)

In another response, the mu sman and the gnyan spirits are reposing on a turquoise mountain, which "is beyond any grown harvest, so the gzed po cannot make shouts" 
(skyes pa'i nI lo 'das gis /// / zed pos nI khus myi gdab //; PT 1051, l. 72). Similarly, we find antelopes on the high meadows who rejoice that they are not harried by hunting shouts (gtsos bu nI snar mtha' ya ne'u sIng nI spang gyI rgyan / / dgyes so nI khus ma gdab; IOL Tib J 738, 1v61-62). The response goes on to give a favourable prognosis for the oracular gambler who, it says, is very compassionate (myI khyod gyi snying rje che ba zhIg pas; 1v63). The same line, of rejoicing at the absence of hunting shouts of "khus!" is found in a further response at IOL Tib J 738, 3v109.

Apart from further bolstering the impression that the hunters are generally the villains within these responses, these hunting calls or shouts appear to draw a clear connecting line between two distinct modes of increasing one's fortune. There is an obvious resemblance between the hunter who shouts "khus!" to hunt and kill an animal and to take sustenance in the form of flesh, bones, sinews, and hides, and the g.yangsummoner who shouts "khu!" while he waves an arrow in one hand and the foreleg of a deer or sheep in the other to obtain the fortunate essence or g.yang that comes ultimately from the slain body of a primordial deer. The arrow, the foreleg, and the image of the hunted deer as the origin of g.yang all certainly support an analogy - if not a direct link -between the hunter and his hunting shout "khus!" and the g.yangsummoner and his call "khu!" or "khu ye!

This parallel directs us to a further, more fundamental problem that has implications for the construction of Tibetan personhood and the play of perspectives within this form of divination. Specifically, if early Tibetan oracular gambling, like g.yang summoning, is a ritual for calling into humans, livestock and domestic space the fortunate essences that reside in wild animals and wild spaces, should one not assume that the oracular gambler would be aligned with the hunters? Is dice divination not a contest with the sman goddesses over phya and g.yang? In the invocations described above, these goddesses are invited into domestic space and offered hospitality in the form of food and drink. As owners of the wild animals and as the main deities invoked, are the sman not the "opponent partners" of the oracular gambler, who in the mode of a hunter tries to take, receive, steal, or win something belonging to the goddesses? Many dice divination responses suggest precisely this.

[Dice rolls:]: 0/0000/0000:

The god Sha med gangs skar says: "You, man, with great strength and a fierce brow, it is the augur ${ }^{35}$ of the enemy youth. Shoot with the sinew-made [bow] at a young wild animal, and take its life. The gods will be pleased, and your wish will come just as you desire, and in the end you will be happy". A good divination.

@@@@@@@@@ :/ / sha med gangs dkargyI zhal nas myI khyod nyam che phral dragIs dgra dar ma'I ngo 'on cIg rkya skyen phongs gyIs rI dags dar ma'I srog chod cIg lha thugs dgyes gyIs snyIng la bsams pa bzhIndu 'ongste mthar skyIde mo bzango. (IOL Tib J 740, 11. 208-211)

In a reversal of this same response, indexed in the same divination text by the combination $0 / 0000 / 0$, the man does not kill the young wild animal, and his fortune is to be attacked from within by enemies in his own village (IOL Tib J 740, 11. 231-234).

Another response clearly identifies the oracular gambler with the hunter, and the image of scattering animals is part of an inauspicious prognosis. This divination begins, "[...] an augur for wild animals and kiang. If you've cast this for hunting, it is an augur that you won't succeed/ won't kill them, and they will scatter" (rI dags dang rkyanggI ngoste rI dags la btab na myI sod gtor pa tsam gyI ngo; IOL Tib J 740, 11. 126-127). 

ritual economy of dice divination.

[Dice rolls:]: 0/000/000:

"Oh! Since you made a good offering to the site,

You killed your hated enemy

Without even worshipping the sku bla.

You killed a deer on the wastes

Without even stungs-ing the sman.

Offer to the gods of the land

And hunt the deer of the north.

Gather your beloved relatives

And strike your enemy's heart with a dagger".

This divination is excellent for whatsoever you've cast it.

/@/@@///@@@/ kye gnas la ni mchod legs pas / sku bla ni ma gsol bar / stang gyi ni

dgra zhig guM / sman tu ni ma stungs par / bas gyi ni sha cig [gu ]m / yul gyi lha gsol dang

/ byang gyi ni sha shor cig / byaMs gyi ni gnyin ${ }^{36}$ bsogs shing / dgra snying ni phur gyis

btab / mo ci la btab kya bzang rab bo. (IOL Tib J 739, 11. 16v1-7)

There is a sense of exultation here at receiving a bounty of fortune without having to attend to the customary strictures of exchange. The most paradigmatic of these is one in which a human makes an offering to a god, and the god then shows favour to the supplicant (Dotson 2017). This act of showing favor ('go ba) or of taking delight (dgyes) is involuntary on the part of the god. These non-volitional verbs signal an uncertain mode of exchange in human acts of ritual persuasion, deception, or coercion, which may or may not succeed. It accords fairly well with the economy of luck or rlung rta observed by Marcia Calkowski among contemporary diaspora Tibetans:

Though humans may endeavour to obtain rlung-rta from the deities by offering them the scent of burning juniper branches, beer, and the entreaties of prayer flags, there is no certainty that such efforts will be rewarded. Rlung-rta is transmitted asymmetrically - the deities confer it at their discretion - that is, from a human perspective, unpredictably. (Calkowski 1993, p. 32)

We can add that in early Tibetan dice divination the god's act of conferring favour, indicated by the non-volitional verb 'go, mirrors the involuntary act of "letting the dice fall" (bab), rather than "casting" or "throwing" them. All of this points to an oblique approach to the exchange at hand, and an avoidance of direct, transactional language. Additionally, this mode of interaction asserts the objectivity of a randomizing divinatory procedure that lacks any volition and which is therefore resistant to tampering.

In the above response the corollary to worshipping the gods (lha) in the case of the sman goddesses has to do with hunting: one should stungs the sman before (or perhaps after) killing a deer. The meaning of this verb is not clear, but it may be aligned with one attested meaning of stung, "to shorten", "to reduce" and "to draw near" (Hill 2010, p. 124). We can be safe in assuming that it points to some form of exchange with this goddess who acts as the guardian and owner of the game animals that the hunters stalk. This sense of a balanced exchange with the divine is obviously the status quo, in that it is duly valourized by the many responses that decry those who would "steal" animals from the sman. This particular response does not enforce this rule but rather confirms it by exulting in its rupture: it asserts that while such a balanced exchange with the divine is normal, an even better exchange is one that is weighted in the human's favour. The response essentially celebrates getting something for nothing, which on the face of it seems to come rather close to the sort of theft of the sman's

Études mongoles et sibériennes, centrasiatiques et tibétaines, 50 | 2019 
animals that other responses decry. Here, however, this unbidden boon or undeserved show of favour, such that the customary exchanges with gods and sman may be foregone, represents a surfeit of fortune on the part of the human oracular gambler. It is an imbalance, but a favourable imbalance to the human's advantage.

\section{Discussion: thieves, owners, and hunters in perspective}

51 How do we comprehend the apparent contradiction between those responses in which the divination client or oracular gambler is aligned by analogy with the hunter and those in which s/he is aligned with the sman goddesses or with the wild animals who, protected by the goddesses, escape the hunt? Is this simply an instance of the widespread mode of ritual deception, so ably deployed by Tibetans when they appeal to the specific perspective of a given spirit or demon to entice it into a trap or trick it into accepting a substitute victim (Ramble 2013)? There seems to be a similar dual perspective at work here, in which the human oracular gambler must be persuasive enough to convince the spirit or demon, but not so persuasive as to deceive him or herself and forget his/her part in the ruse. The specific dynamics of exchange in early Tibetan dice divination or oracular gambling are consciously constructed by an analogy with hunting, and it is here that the perspective of the hunter illuminates that of the oracular gambler.

As we have seen, the sman are the owners of the wild game ( $r$ dags) who stand in relation to them as "livestock" (phyugs). From this perspective, hunters are cattle rustlers or "thieves". Here it is through animals, and their contested nature as either $r i$ dags on the one hand or phyugs on the other that human's and sman goddess's perspectives can be said to compete. Ludek Broz has written about strikingly similar dynamics among Altai hunters who also interact with spirits called eezi who are "owners of place" and who own the wild animals (an or andar-kushtar) in much the same way as sman, sa bdag, or mountain gods in Tibet. Here, in what Broz, drawing on the seminal work of Viveiros de Castro, calls "pastoral perspectivism", the eezi spirits refer to their deer as mal, the Altaian term for "livestock", and they guard these against theft from hunters whom the eezi spirits often view as baryntychy, a term that means both "thieves" and "predators" (Broz 2007, pp. 293-29737). For Broz, this exchange is not an incommensurable relationship of predation and appropriation in which the hunters are always "thieves": by acting within measure, they can occupy the space of "hunter" (anchy) rather than "thief" (baryntychy) (Broz 2007, p. 297). This sense of balance is what Broz defines as "morality": he states that "it is morality which enables one to legitimately impose one's perspective", that is, to transform the god's mal into the hunter's an (Broz 2007, p. 299). For Broz, morality "exists at the point of confrontation of domains, it equals resolution" (Broz 2007, p. 308, n. 19).

Such balance at the point of exchange does not apply to Tibetan oracular gambling, where hunter and thief are synonyms. Rather, balance appears to be reestablished by subsequent actions in the manner of a correction. As we have seen, there is an ethic of reciprocity: one should make offerings to the gods in order to win their favour, and one should make exchanges with the sman goddesses before (or after) taking their animals. But this does not erase the underlying agonistic dynamics of both hunting and oracular gambling. From the perspective of a game or a contest, there is a strong balance of agon 
and alea, but the human side plays offense, so to speak, while the divine side plays defence ${ }^{38}$. Even so, humans stake something and risk something, as is evident from the various stories in which mountain gods or goddesses transform the human hunter into prey, causing his fellow hunters to kill him (da Col 2007, pp. 226-228), and as seen above in the case of the dire prognoses an oracular gambler can receive. The end result - the meeting of perspectives and "resolution" - is only "successful" in oracular gambling when the human side wins. There is no way around the fact that this is a loss for the divine or animal side. This is most obvious from the rituals of compensation, where people perform g.yang-summoning rituals on behalf of mountain gods, create "fortune vases" (g.yang 'bum) and bury fortunate substances in the mountain's domain, or release animals consecrated to the mountain as a transfer from domestic to wild space in the ritual of "life liberation" (tshe thar) (da Col 2012a, pp. 85, 90). The sentiment is also clear in one of the oracular responses translated above: "if one repays a debt of fortune with fortune (phyva), it is good" (pya bun gyI phyva blan na bzango /; IOL Tib J $740,1.227)$. This does not signify balance at the point of exchange, but rather the redressing of imbalances produced at the point of exchange, and the restocking of depleted reserves ${ }^{39}$.

Another hunting dynamic - the hunter's dual perspective as hunter and, mimetically as (imitator of) prey - may offer the key to unlocking the perceived incommensurability of human and divine perspectives and the imbalance of a "successful" exchange in Tibetan oracular gambling. To successfully stalk and kill animals, a hunter must to some extent adopt the perspective of his or her prey while also retaining sufficient grasp of his or her own human identity as hunter. Rane Willerslev describes the mimesis involved in a hunter's dual perspective in the context of the Yukaghirs of Siberia:

When a hunter mimics the elk to bring it into the open so that he can shoot at it, he acts simultaneously within two motivational spaces, which could be called "the space of predatory mastery" and "the space of animal imitation". The first has to do with the hunter's intention of killing the animal, the second with his need to take on its identity in order to fulfill that intention. The hunter, we might say, acts with a dual nature: he is both hunter and animal. To act in between these two identities is a highly complex task. If he lets his intentions as a hunter show through his actions, the prey animal will either run or attack him. If, on the other hand, he allows his intentions to merge with his bodily movements (which are that of an elk), he will surrender to the perspective of prey and turn into it. The hunter therefore needs to be aware not only of the prey animal, but also of himself being aware of the prey, in order to make sure that his perspective is neither that of a hunter nor that of the animal, but instead somewhere in between or both at once. In other words, the success of the hunter depends upon his ability to keep up a double perspective, or act as a mimetic agent. (Willerslev 2007, pp. 96-97)

It is precisely this dual perspective of the hunter that I believe accounts for the apparent ambiguity in early Tibetan dice divination with respect to the changing perspectives of the oracular gambler as aligned with the hunter on the one hand and as aligned with the sman goddesses or game animals on the other. The ritual setting of early Tibetan dice divination, and the cosmology that the oracular responses themselves reinforce strongly suggests a similar dynamic between the human oracular gambler and the sman goddesses who are the caretakers of fortune. Called down from the heavens and the highlands and into the domestic ritual space in the opening invocation preceding the dice divination, the sman goddesses, like the hunted animals, are objects of what Willerslev calls "mimetic empathy" (Willerslev 2007, pp. 105-110), 
and they are what I refer to in the context of oracular gambling as "opponentpartners". This is what is at play when the responses align the oracular gambler's perspective with that of the sman goddess or her animals. Like a hunter, the gambler must hide his true intentions from the sman goddesses from whom he will win fortune. Revealing his true face too soon, he would be recognized as something like a thief or hunter coming to steal the sman's property. On the other hand, for the oracular gambler to adopt only the perspective of the sman goddesses and their wild animals would be to fail to rise to the occasion of what is ultimately an agonistic competition for fortune. Just as the deer is in the end the hunter's prey, so too is there in oracular gambling an unavoidable contest with the sman goddesses over fortune. This human perspective - Willerslev's "space of predatory mastery", albeit in a divinatory context is clear from the responses in which the oracular gambler is aligned with the hunter, and where the kill is a good augur.

We have already emphasized the sman goddess' movement downward into domestic space to accept human hospitality in the invocations preliminary to oracular gambling. There is also an inverse movement on the part of the oracular gambler. In his/her dual perspective s/he moves upward into the highlands where the animals and the sman goddesses dwell. This perspective is fundamentally equivocal in that the gambler is aligned sometimes with the hunters and other times with hunted animals. There is a further ambiguity in the latter perspective, since to identify with the game animals is also by extension to align the gambler with the animals' owners, the sman goddesses. Oracular gambling thus pushes the gambler not only to traverse the distance between domestic, low-lying space and the wild upland space, but also that between human and animal, human and divine, and - assuming a male oracular gambler - male and female. This again recalls Yukaghir hunter, who through his exercise of mimetic empathy and his shifting perspectives experiences a "crisis of self image, not only in terms of his species identity, but also in terms of his gender identity: he is neither male nor female, as he is neither human nor animal. He becomes, so to speak, polymorphous" (Willerslev 2007, p. 113). This movement across and between dichotomies in Tibetan oracular gambling also has echoes in the mythology of Indian dicing, as when the unity of the androgynous godhead is fragmented into the male god Siva and the goddess Pārvatī through the game of dice, or when the human gambler Nirankuśa defeats the god Śiva to become "more god than god" (Handelman \& Shulman 1997, p. 25, 96-10640).

This sense of being drawn in two ways at one time, of identifying simultaneously with the wild target either of hunting or of divination while remaining the human hunter or oracular gambler, dissolves in the end back into the human perspective. While both human and divine (or predator and prey) perspectives can be held at once, they are incommensurable and they are in competition with one another such that only one will prevail. The animals will be either the hunter's wild game ( $r$ dags) or the sman goddesses' "livestock" (phyugs); the oracular gambler will either win fortune from the sman and her wild spaces, or lose fortune - though a draw is also possible. In this hospitality setting in which the sman goddesses are invited to compete with the oracular gambler, it is the dice that decide which perspective and which party will prevail. The perceived objectivity of the dice, and their ability to fall decisively one way or the other facilitates the exchange and makes the oracular gambler's victory something more legitimate than an act of theft. 
The analogies with hunting are a case where oracular poetry lays bare the dynamics of exchange by revealing the risk involved in the sman goddess' acceptance of the gambler's gift of hospitality. The sman goddesses and their wild "livestock" offer a divine mirror image of humans and their domestic livestock. In this mirror image, each member of each pair is defined in relation to its partner: humans are partly constituted by their livestock, and livestock by their human owners; sman are partly constituted by their "livestock", and wild animals by their sman owners. At the same time, each is also defined by its difference from and interaction with its counterpart, or other: sman goddesses are defined in relation to humans, and humans in relation to sman goddesses; wild animals are defined in relation to livestock, and livestock in relation to wild animals. Oracular gambling, in its characteristically oblique fashion, has the gambler act not on his divine counterpart herself, but on her possessions, the wild animals, by trying to take them (and the fortune they represent) in his guise as hunter. These possessions - which also constitute part of her own divine personhood - are what the goddess has in effect staked by accepting the gambler's hospitality. The inverse situation, incidentally, would be one where the goddess steals a person's livestock, which would presumably mean the livestock would become ill or die. More literally, it would be for the goddess to make these animals become wild. This is in fact what is more or less pre-empted or even performed when livestock animals are offered to the gods as "god sheep", "god yaks", etc., and left to roam free in the ritual of "life liberation" (tshe thar), one of the main strategies for restocking the fortune of a god, goddess, or place (Holler 2002, da Col 2012a, pp. 85, 90). It is a further indication of how the sensibilities of early Tibetan oracular gambling align with assumptions about human-divine exchanges that continue to inform Tibetan rituals to this day.

\section{Conclusion}

Oracular gambling is a highly specific means of accessing fortune and interacting with caretakers of fortune such as sman goddesses. It contrasts with more predictable, scripted rituals for calling in fortune, which do not involve the same degree of hospitality offered to the gods and the sman goddesses and which entail less risk. At the heart of oracular gambling, animals index the competing perspectives of human diviners and sman goddesses. It is a contest where if the human side is successful, the animals go from being the goddesses' livestock to becoming the hunter's wild game, a transformation that simultaneously represents the flow of fortune from the sman goddesses and their wild spaces to the oracular gambler and his or her domestic spaces. This transfer of fortunate essence is also marked by inverse ontological and/or positional movements on the part of the oracular gambler and his "opponent partner", the sman goddess. Accepting the gambler's hospitality, she descends into human, domestic space, leaving her possessions - her wild "livestock", and, metaphorically, fortune - at risk to predation. Casting the dice (or rather, "allowing them to fall"), the successful oracular gambler moves upward into these spaces, partly "becoming" both animal and goddess in order to appropriate this fortunate essence. The operation is obviously fraught with risk, and its success or failure is entirely determined by the fall of the dice.

60 Amid these inverse movements of goddesses and gamblers, it is hard to escape the impression that the animals such as deer, antelopes, and yaks are static, and undertake 
no comparable ontological or positional shift. It is only their status that changes from divine livestock to human prey vis-à-vis the shifting perspectives of which they seem to be only the objects. Following the ritual of oracular gambling and the dissolving of these competing perspectives, however, the reverse may be said to be true, since the gambler remains a human in domestic space and the goddess remains divine in her highland environs, and it is only the animals (or rather, their metaphorical corollaries, the fortunate essences) that have shifted from one place to the other. As such, an animal like the deer is both a supreme symbol of these economies of fortune and their transactions, and an embodiment of a mutual relatedness performed through the circulation of fortune between humans, gods, livestock, and wild animals.

\section{BIBLIOGRAPHY}

Bacot, J. 1913 La table des présages signifiés par l'éclair, Journal Asiatique 1, pp. 445-449.

Bellezza, J. V. 2005 Spirit-Mediums, Sacred Mountains and Related Bon Textual Traditions in Upper Tibet. Calling Down the Gods (Leiden, Brill).

Berounský, D. 2014 Tibetan myths on "good fortune" (phya) and "well being" (g.yang), MongoloTibetica-Pragensia 7(2), pp. 55-77.

Bialek, J. 2018 Compounds and Compounding in Old Tibetan. A Corpus Based Approach (Marburg, Indica et Tibetica Verlag).

Broz, L. 2007 Pastoral perspectivism. A view from Altai, Inner Asia 9, pp. 291-310.

Broz, L. \& W. Willerslev 2012 When good luck is bad fortune. Between too little and too much hunting success in Siberia, Social Analysis 56(2), pp. 73-89.

Caillois, R. [1958] 1961 Man, Play and Games, translated by M. Barash (Urbana, University of Illinois Press).

Calkowski, M. 1993 Contesting hierarchy. On gambling as an authoritative resource in Tibetan refugee society, in C. Ramble \& M. Brauen (eds), Anthropology of Tibet and the Himalaya (Zurich, Ethnological Museum of the University of Zurich), pp. 30-38.

Col, G. da 2007 The view from somewhen: events, bodies and the perspective of fortune around Kawa Karpo, a Tibetan sacred mountain in Yunnan province, Inner Asia 9, pp. 215-235.

2012a The elementary economies of Dechenwa life. Fortune, vitality, and the mountain in SinoTibetan borderlands, Social Analysis 56(1), pp. 74-98.

$2012 \mathrm{~b}$ The poisoner and the parasite. Cosmoeconomics, fear, and hospitality among Dechen Tibetans, Journal of the Royal Anthropological Institute 18, pp. 175-195.

Dotson, B. 2013 The princess and the yak. The hunt as narrative trope and historical reality, in B. Dotson, K. Iwao \& T. Takeuchi (eds), Scribes, Texts, and Rituals in Early Tibet and Dunhuang (Wiesbaden, Reichert Verlag), pp. 61-85.

2015a The call of the cuckoo to the thin sheep of spring. Healing and fortune in Old Tibetan dice divination texts, in C. Ramble \& U. Roesler (eds), Tibetan and Himalayan Healing. An Anthology for Anthony Aris (Kathmandu, Vajra Publications), pp. 147-160. 
2015b Introducing early Tibetan law. Codes and cases, in D. Schuh (ed.), Secular Law and Order in the Tibetan Highland (Andiast, International Institute for Tibetan and Buddhist Studies), pp. 267-314.

2017 On 'personal protective deities' ('go ba'i lha) and the Old Tibetan verb 'go, Bulletin of the School of Oriental and African Studies 80(3), pp. 525-545.

2018a The horse and the grass-grazing man. Domestication, food, and alterity in early Tibetan cosmologies of the land of the dead, History of Religions 57(3), pp. 270-287.

2018b A fragment of an early Tibetan divination board from Mīrān, in V. Caumanns, M. Sernesi \& N. Solmsdorf (eds), Unearthing Himalayan Treasures. Festschrift for Franz-Karl Ehrhard (Marburg, Indica et Tibetica Verlag).

Govindrajan, R. 2018 Animal Intimacies. Interspecies Relatedness in India's Central Himalayas (Chicago, University of Chicago Press).

Handelman, D. \& D. Shulman. 1997 God Inside Out. Śiva's Game of Dice (Oxford, Oxford University Press).

Hill, N. 2010 A Lexicon of Tibetan Verb Stems as Reported by the Grammatical Tradition (München, Verlag der Bayerischen Akademie der Wissenschaften in Kommission Beim Verlag C. H. Beck).

Holler, D. 2002 The ritual of freeing lives, in H. Blezer (ed.), Religion and Secular Culture in Tibet (Leiden, Brill), pp. 207-226.

Huber, T. 2004 Territorial control by "sealing" (rgya sdom-pa). A religio-political practice in Tibet, Zentralasiatischestudien 33, pp. 127-152.

Kalinowski, M. 1994 La divination par les nombres dans les manuscrits de Dunhuang, in I. Ang \& P.-É. Will (eds), Nombres, astres, plantes et viscères. Sept essais sur l'histoire des sciences et des techniques en Asie orientale (Paris, Institute des hautes études chinoises), pp. 37-88.

Karmay, S. G. [1993] 1998 The windhorse and the well-being of man, in S. G. Karmay, The Arrow and the Spindle (Kathmandu, Mandala Book Point), pp. 413-422.

Karmay, S. G. \& Y. Nagano 2002 The Call of the Blue Cuckoo. An Anthology of Nine Bonpo Texts on Myths and Rituals (Osaka, National Museum of Ethnology).

Kelényi, B. 2003 The cult of good luck, in B. Kelényi (ed.), Demons and Protectors. Folk Religion in Tibetan and Mongolian Buddhism (Budapest, Ferenc Hopp Museum of Eastern Asiatic Art), pp. 47-77. Laufer, B. 1914 Bird divination among the Tibetans, T'oung Pao 15, pp. 1-110.

Lévi-Strauss, C. [1962] 1963 Totemism, translated by Rodney Needham (Boston, Beacon Press). Lichter, D. \& L. Epstein 1983 Irony in Tibetan notions of the good life, in C. Keyes \& E. V. Daniel (eds), Karma. An Anthropological Inquiry (Berkeley, University of California Press), pp. 83-118.

Macdonald, A. 1971 Une lecture des Pelliot tibétain 1286, 1287, 1038, et 1290. Essai sur la formation et l'emploi des mythes politiques dans la religion royale de Srong bcan Sgam po, in Études Tibétaines dédiées à la mémoire de Marcelle Lalou (Paris, Adrien Maisonneuve), pp. 190-391.

Makley, C. 2018 The Battle for Fortune. State-Led Development, Personhood, and Power Among Tibetans in China (Ithaca, Cornell University Press).

Manetti, G. [1987] 1993 Theories of the Sign in Classical Antiquity, translated by C. Richardson (Bloomington, Indiana University Press).

Michon, D. 2015 Archaeology and Religion in Early Northwest India. History, Theory, Practice (New Delhi, Routledge). 
Murakami, D. 2014 Aspects of the traditional gambling game known as sho in modern Lhasareligious and gendered worldviews infusing the Tibetan dice game, Revue d'Etudes Tibétaines 29, pp. 245-270.

Nebesky-Wojkowitz, R. [1956] 1998 Oracles and Demons of Tibet. The Cult and Iconography of Tibetan Protective Deities (Delhi, Classics India Publications).

Nishida, A. 西田愛. 2008 古チベット語サイコロ占い文書の研究 [A study of Old Tibetan dice divination], 日本西藏学会夕辗 [Report of the Japanese Association for Tibetan Studies] 54, pp. 63-77.

2011 An Old Tibetan divination with coins. IOL Tib J 742, in Y. Imaeda, M. T. Kapstein \&

T. Takeuchi (eds), New Studies of the Old Tibetan Documents. Philology, History and Religion (Tokyo, Institute for the Languages and Cultures of Africa and Asia), pp. 315-327.

2013 Bird divination in Old Tibetan texts, in Current Issues and Progress in Tibetan Studies. Proceedings of the Third International Seminar of Young Tibetologists, Kobe 2012 (Kobe, Kobe City University of Foreign Studies), pp. 317-341.

In press A preliminary analysis of Old Tibetan dice divination texts, in D. Rossi, P. Maurer \& R. Scheuermann (eds), Glimpses of Tibetan Divination, Past and Present (Leiden, Brill).

Norbu, N. 1997 Drung, De'u and Bon. Narrations, Symbolic Languages and the Bön Tradition in Ancient Tibet, translated by A. Clemente and A Lukianowicz (Dharamsala, Library of Tibetan Works and Archives).

Peek, P. 1991 Introduction. The study of divination, past and present, in P. Peek (ed.), African Divination Systems (Bloomington, Indiana University Press), pp. 1-22.

Ramble, C. 1996 Patterns of places, in A.-M. Blondeau \& E. Steinkellner (eds), Reflections on the Mountain (Wien, Verlag der Österreichischen Akademie der Wissenschaften), pp. 141-153. 2013 Both fish and fowl? Preliminary reflections on some representations of a Tibetan mirrorworld, in F.-K. Ehrhard \& P. Maurer (eds), Nepalica-Tibetica. Festgabe for Christoph Cüppers (Andiast, International Institute for Tibetan and Buddhist Studies), pp. 75-89.

2015 The deer as a structuring principle in certain Bonpo rituals. A comparison of three texts for the acquisition of good fortune (g.yang), in P. McAllister, C.A. Scherrer-Schaub \& H. Krasser (eds), Cultural Flows across the Western Himalaya (Wien, Verlag der Österreichischen Akademie der Wissenschaften), pp. 509-540.

Richardson, H. E. [1990] 1998 Hunting accidents in early Tibet, in H. E. Richardson, High Peaks Pure Earth, edited by Michael Aris (London, Serindia), pp. 149-166.

Stein, R. A. 1970-1971 Étude du monde chinois. Institutions et concepts, Annuaire du Collège de France 71 éme Année, Résumé des Cours de 1970-1971, pp. 431-450.

2010 Rolf Stein's Tibetica Antiqua, translated by Arthur McKeown (Leiden, Brill).

Strickmann, M. 2005 Chinese Poetry and Prophecy. The Written Oracle in East Asia (Stanford, Stanford University Press).

Swancutt, K. 2012 Fortune and the Cursed. The Sliding Scale of Time in Mongolian Divination (New York, Bergahn Books).

Takeuchi, T. 2012 Formation and transformation of Old Tibetan, in T. Takeuchi \& N. Hayashi (eds), Historical Development of the Tibetan Languages. Proceedings of the Workshop B of the $17^{\text {th }}$ Himalayan Languages Symposium, Kobe 2011, Journal of the Research Institute of Foreign Studies 49, pp. 3-17.

Tekin, T. 1994 Irk Bitig. The Book of Omens (Wiesbaden, Otto Harrassowitz). 
Thomas, F. W. 1957 Ancient Folk-Literature from North-Eastern Tibet (Berlin, Akademie-Verlag).

Uray, G. 1966. 'Greng, the alleged Old Tibetan equivalent of the ethnic name Ch'iang, Acta Orientalia Hungaricae 19(3), pp. 245-256.

Viveiros de Castro, E. 2004 Perspectival anthropology and the method of controlled equivocation, Tipiti: Journal of the Society for the Anthropology of Lowland South America 2(1), pp. 3-22.

White, D. G. 1995 Predicting the future with dogs, in D. S. Lopez, Jr. (ed.), Religions of India in Practice (Princeton, Princeton University Press), pp. 288-303.

Willerslev, R. 2007 Soul Hunters. Hunting, Animism, and Personhood among the Siberian Yukaghirs (Berkeley, University of California Press).

\section{NOTES}

1. The research going into this article was supported by a visiting fellowship during 2015-2016 and summer 2017 at the International Consortium for Research in the Humanities, "Fate, Freedom and Prognostication: Strategies for Coping with the Future in East Asia and Europe," at the University of Erlangen-Nuremberg, generously funded by the German Federal Ministry of Education and Research (BMBF). I would also like to thank the Animals and Religion Unit at the American Academy of Religion, where I presented some of this research in November 2015, and the Centre for Buddhist Studies Reading Group at the University of Toronto, which discussed a draft of this article with me in April 2018.

2. For a recent, exemplary ethnographic work, see Govindrajan 2018.

3. On the horse as a human partner across life and death, see Dotson 2018a.

4. The verses for the dice combination $4 / 4 / 2$ include images of horses and yaks, followed by this interpretation: "if you've cast this as a horse divination, no evil whatsoever shall come. Good" (rta 'i mor btab na ci yang myi nyes te bzang ngo; IOL Tib J 739, 4r8).

5. See, for example, PT 55, 11. 118-155.

6. Raven divination, for example, came to Tibet from India, while coin divination came from China (Nishida 2013, Nishida 2011).

7. These are the Irq Bitig and the Moxishouluo bu, respectively; see Tekin 1994 and Kalinowski 1994, pp. 63-64.

8. This is discussed in Thomas 1957, pp. 141-146, Nishida 2008, pp. 70-71, and Dotson 2015, p. 152.

9. For a detailed typology and a structural analysis of the entries, which distinguishes many subelements in addition to these four main components, see Nishida 2008 and Nishida forthcoming.

10. Ai Nishida, building on the work of F. W. Thomas and Rolf Stein, distinguishes two main subtypes of early Tibetan dice divination. Type one features oracles in verse that do not generally issue from the mouth of a deity, whereas type two features prose oracles that usually do come from a named deity (Nishida 2008, pp. 66-68).

11. On the application of the terms "omen" and "oracle" to protasis and apodosis in Giovanni Manetti's semiotic study of divination in the ancient world, see Manetti 1993, pp. 6-7. One should note here the range of the term "oracle," which can refer to the human/divine or textual source of an oracular utterance on the one hand, and to the utterance itself on the other. In consideration of the ritual setting of diviner, querent(s), and bystanders who might constitute a "divinatory congregation," the "interpretation" could be more accurately described as a "preinterpretation" prior to a larger discussion between the participants (Peek 1991, p. 3).

12. I borrow the term "correcting rituals" from Katherine Swancutt. In the context of Mongolian divination that she describes, "correcting rituals" are often innovative rituals to remedy a situation of misfortune revealed by divination (Swancutt 2012). In early Tibetan dice divination 
by contrast, it appears to be rather a case of creating, rather than revealing, one's (un)fortunate situation with respect to gods and sman goddesses.

13. Read byi.

14. In early Tibetan sources there is a tendency to use phya in compounds such as srog phya, and phyva where the term stands on its own.

15. Read ni.

16. There are a few small philological points to mention regarding this translation. First, khyung mkhar may be an error for sku mkhar: see lha rje ni sku mkhar la in an entry at IOL Tib J 739, 15r6. Second, "receive" is a very free translation of skyobs, which I take to be the imperative stem of a verb related khyab "to pervade". Third, for dog, which means "narrow", and often appears in the expression sa dog "narrow earth", or on its own as a metonymy for "earth", the parallelism implies that myi is to 'greng as phyugs is to dog. The verb byams, "to become gentle", further supports the assumption that dog does not refer to earth or soil, but I am otherwise unable to marshal further supporting evidence for a claim that dog somehow means "livestock". I am inclined to assume, therefore, a scribal error, where one would hope for dud, as in the wellknown pair of 'greng and dud - the "upright" and the "bent over" - for humans and (some) animals (Uray 1966). These sorts of speculations would be inadmissible in more regimented textual genres, but the evidence of parallel oracular responses has clearly established that these texts are fraught with errors, which in itself is a key datum for their Sitz im Leben (Thomas 1957, pp. 146-150, Nishida forthcoming). For an alternative translation of this passage, where the god in the first line is "loving towards the earth" see Bialek 2018, p. 573.

17. IOL Tib J 738, 3v14: phyva' bos nI g.yang re nyams / / nyams cung nI dbugs re phra; here one should read bros for bos.

18. The term $p(h) y a$ bun, here translated as "debt of fortune," appears seventeen times in the dice divination text IOL Tib J 1047 and three times in IOL Tib J 740. In every case apart from the passage just translated, it appears to refer to objects or to combinations of objects. On the various terms for these objects or combinations, and on the putative use of boards in early Tibetan dice divination, see Macdonald 1971, pp. 272-286 and Dotson 2018b.

19. In the law of accidental homicide, the law of dog bite, and the law of theft, we find a ratio of $14 p(h) y u g s$ nor to $36 p(h) y u g$ nor. This could conceivably be taken to suggest a compounding process by which phyugs nor gave way to phyug nor. For an overview of these and other early Tibetan legal texts, and their relationship to dice divination texts, see Dotson 2015b.

20. Charlene Makley also describes similar assumptions about g.yang in Rebgong (Makley 2018, pp. 50-54).

21. Drawing on Prytz-Johansen, da Col writes, “[m]ana is not an entity or an 'energy' but a state: the state of being in mystical relationality with forces which enhance and unfold one's vitality and leadership. Likewise, an economy of fortune is foregrounded on technologies of attachment or containment of humans, non-human beings and objects associated with yang, including household and territorial gods, in order to constitute a fellowship of fortune" (da Col 2012b, p. 188); italics in original.

22. Daniel Michon employs this term in his treatment of pāśaka dice divination at Sirkap, but his definition of oracular gambling, "using dice throws to both predict and control the future," has ostensibly little to do with gambling, and could more accurately describe dice divination generally (Michon 2015, p. 183, n. 64). I borrow therefore only the term "oracular gambling," which I employ to highlight the elements of contest, risk, and chance in dice divination. David White also uses the term "oracular gambling," but only in passing (White 1995, p. 288).

23. @ / @@@@ / @@@ / kye mu sman ni zhal na re / sman ri ni ya byi na zlog par ni ma 'drol kyang sha shor ni phas kyang mchi / lgo 'drim ni tshus kyang mchi de 'is ni nyams myi skyod / skyo le ni bdag gyi nor / stus shing ni ra bar gsol / bzang rab bo. (IOL Tib J 739, 16r5-9) 
24. This closely parallels the process by which humans domesticated horses in the Tibetan myth of horse-domestication, where the horse is enticed into a paddock. On the importance of this image, and the place of domestication and "un-domestication" in early Tibetan death rituals, see Dotson 2018a.

25. See Huber 2004, pp. 138-139, da Col 2007, pp. 216-217, 2012a, p. 180, 2012b, pp. 87 and 94, n. 14 .

26. The response is also found in another dice divination text, PT 1051: myi khyod la yul gdon dang //// pho srid za'am / / / / ma legs pa dang / / mchi bar'ong ngo / / / gdon 'di ltar za bas sems kyang khyugs phyva dang bros shing 'dug ste/ / / / bag gyis shig / / nad pa la btab na ngan rab ste mchi 'o / /; PT 1051, 1l. 61-63. Cf. IOL Tib J 738, 3v39-42 (Read 'chi for mchi for the final verb).

27. PT 1052 has lho, so these are probably to be read as the southern mountain and the northern mountain.

28. Read gzed.

29. Read dgyes.

30. Read 'dre.

31. Read na.

32. Read don.

33. Compare with Macdonald 1971, p. 296, and the parallel omen at PT 1052, 1l. r86-94.

34. Given that khus and ki are near homophones in Amdo dialect, one could speculate that this fortunate shout is also the origin of the otherwise inexplicable ki ki in the victory shout " $k i k i$ so so lha rgyal lo", itself associated with victory and with high spaces.

35. The word ngo, and its honorific equivalent zhal, is used consistently in early Tibetan dice divination, where it functions almost as a synonym for mo, but tends to be used in the context of the future-oriented prognosis or interpretation. Its precise semantic range in a divinatory context remains to be clarified.

36. Read gnyen.

37. This draws on, but actively modifies Eduardo Viveiros de Castro's articulation of Amazonian perspectivism, for which see, for example, Viveiros de Castro 2004.

38. On the categories of agon (competition) and alea (chance) in relation to a highly influential typology of play, see Caillois 1961.

39. Oracular gambling's use of the idiom of hunting suggests a dynamic of oscillating surplus and deficit akin to one in which a game-giving spirit might be obliged to "give" to the hunters or "share" its bounty with a hunter in times of plenty, but where hunting animals in times of scarcity, etc., would constitute theft on the part of the hunters. On this point, see Broz \& Willerslev 2012.

40. Obviously there is much more to be said about gender, sexuality, and boundary crossing in Tibetan oracular gambling and in the mythology of dice and dice games in Tibet. One notes in passing that gender dynamics have a practical implication for dice gambling in Lhasa: men do not generally allow women to play, since women, favoured by the goddess dPal ldan lha mo, they are said to always win (Murakami 2014). 


\section{ABSTRACTS}

Deer, antelope, gazelles, and other wild animals are central to early Tibetan dice divination. They appear in response after oracular response in approximately two dozen $9^{\text {th }}$ and $10^{\text {th }}$-century excavated dice divination manuscripts recovered from Dunhuang, Turfan, and other sites occupied by Tibetans along the southern Silk Road in the $8^{\text {th }}$ and $9^{\text {th }}$ centuries. In addition to deer, kiang, yaks, and so on, various birds and waterfowl make repeated appearances in the responses. These animals, whose preponderance has been remarked upon by others who have studied these texts, are more than just a picturesque evocation of Tibetan fauna. And they do more than simply bear witness to a process whereby Tibetans assimilated a foreign divinatory technology and infused it with their own poetic and oracular sensibilities. These seemingly omnipresent wild animals are in fact central to the exchanges between the wild and the tame, and between the divine and the human that underpin a larger ritual economy of fortune to which dice divination offers one very specific mode of access. As repositories of fortune, and as the favoured possessions of the wild sman goddesses who oversee the wild highlands, these wild animals index a competition wherein there lies a subtle balance between agonistic struggle and aleatory hazard. For a divination client or "oracular gambler", human fortune (phya) may be won - essentially taken from the wild spaces overseen by the sman goddesses -, or it may be lost, often with grave results. This dynamic of exchange, in which the fortunate essence of the wild is absorbed by humans and livestock, also raises intriguing questions about the relationship between dice divination and hunting and, more generally, about animals and divinities in the construction of Tibetan personhood.

Le cerf, l'antilope, la gazelle et d'autres animaux sauvages sont au cœur de la divination par les dés dans le Tibet ancien. On les trouve dans les présages successifs d'environ deux douzaines de manuscrits de divination par les dés des $\mathrm{IX}^{\mathrm{e}}$ et $\mathrm{X}^{\mathrm{e}}$ siècles, retrouvés à Dunhuang, Turfan et autres sites occupés par les Tibétains le long de la route sud de la soie aux $\mathrm{VIII}^{\mathrm{e}}$ et $\mathrm{IX}^{\mathrm{e}}$ siècles. En plus des cerfs, kiang et yaks, diverses espèces d'oiseaux et de gibier d'eau apparaissent à intervalles réguliers dans les présages. Ces animaux, dont la prépondérance a été relevée par d'autres chercheurs, sont plus qu'une évocation pittoresque de la faune tibétaine. Et ils font plus que simplement témoigner d'un processus par lequel les Tibétains ont assimilé une technologie divinatoire étrangère, imprégnant ces présages de leur propre sensibilité poétique et oraculaire. Ces animaux sauvages, de toute évidence omniprésents dans les présages, sont en fait essentiels aux échanges entre le sauvage et le domestiqué, et entre le divin et l'humain qui sous-tendent une plus grande économie rituelle de la fortune à laquelle la divination par les dés offre un mode d'accès très spécifique. Ces animaux sauvages se trouvent en concurrence en tant que dépositaires de la fortune et en tant que biens privilégiés des déesses sauvages sman qui surveillent les hauts plateaux sauvages, concurrence qui respecte un équilibre subtil entre la lutte (agonistique) et le hasard (aléatoire). Pour un client de la divination ou «joueur oraculaire ", la fortune humaine (phya) peut être gagnée - essentiellement à partir des espaces sauvages surveillés par les déesses sman-, ou bien elle peut être perdue, souvent avec des résultats graves. Cette dynamique d'échange, dans laquelle l'essence faste du sauvage est absorbée par les humains et leur bétail, soulève également des questions intrigantes sur la relation entre la divination par les dés et la chasse et, plus généralement, sur le rôle que jouent les animaux et les divinités dans la construction de la personne tibétaine. 
INDEX

Mots-clés: Tibet, manuscrit, chasse, fortune, divination, rituel, jouer

Keywords: Tibet, manuscript, hunting, fortune, divination, ritual, play

\section{AUTHOR}

\section{BRANDON DOTSON}

Brandon Dotson is an Associate Professor and McKenna Chair of Buddhist Studies at Georgetown University. His research concerns the relationship between Buddhist and non-Buddhist traditions in Tibet, particularly in the areas of cosmology, ritual, and narrative. His most recent publications include a co-authored book, Codicology, Paleography, and Orthography of Early Tibetan Documents (Vienna, 2016) and the edited collection Kingship, Ritual, and Narrative in Tibet and the Surrounding Cultural Area (Cahiers d'Extrême-Asie 24, 2015).

Brandon.dotson@georgetown.edu 